\title{
姿勢の違いによる高齢男性への地震動の影響分析 \\ INFLUENCE ANALYSIS OF SEISMIC GROUND MOTION \\ ON ELDERLY MALES BY DIFFERENCE IN POSTURES
}

\author{
建部謙治*1, 井出政芳*2, 加藤 憲*3, 野澤英 希*4 \\ Kenji TATEBE, Masayoshi IDE, Ken KATO \\ and Hideki NOZAWA
}

\begin{abstract}
The purpose of this research was to make clear the physiological and psychological influence of earthquake motion in posture. "Sense of seismic ground motion strength" and systolic blood pressure showed significant difference between Chair seat position and Face up position. It's possible to predict "sense of seismic ground motion strength" from posture by multi regression analysis.
\end{abstract}

Keywords : Earthquake Motion, Elderly People, Posture, Influence, Experiment 地震動, 高齢者, 姿勢, 影響, 実験

\section{1. 序論}

\section{1 研究の背景と目的}

近年、日本各地で地震が発生し、地震発生の報道を見ない日が無 いくらい頻繁に緊急地震速報等が流れている。

一方、近い将来首都直下地震や南海トラフ巨大地震の到来も懸念 されている。こうした状況下で、さらなる地震防災対策が求められ ている。

地震災害に対して建物の耐震化や避難情報の在り方などが長年検 討されている中で、人間個々の行動特性を踏まえた地震時の対処方 法の検討も必要である。特に地震発生の時間帯によっては、椅子座 位、仰臥位など様々な姿勢で強震動を受けることが想定され、地震 動の姿勢による影響も理解する必要がある。

既往研究を見ると、振動による研究はいくつか見られる。しか し、筆者らによる研究を除くと、姿勢に関しては小竹ら ${ }^{1)}$ による強 地震動下での立位姿勢制御の老化による影響に関する研究が見られ る程度で、姿勢の違いによる地震動の影響を考慮した防災対策に関 する研究はほとんど見られないのが現状である。

\section{2 研究目的}

本研究では、高齢男性の地震発生時における姿勢の違いによる地 震動の生理・心理学的影響について明らかにすることを目的とす る。こうした成果にもとづき、夜間時や暗闇時における対処行動に 関する知見を得ることを目指す。

\section{2. 研究方法}

\section{1 実験方法}

研究は、緊急地震速報情報の受信時間とほぼ「同時」に振動台の 実験室（Fig.1）で強い地震動を被験者が暗闇時注1)に体験する実験 （Ex.1 と Ex.2）を 2 力年にわたって行った。入力する地震波は、 1995 年兵庫県南部地震における神戸海洋気象台の NS の地震波を 最大速度 $50 \mathrm{~cm} / \mathrm{sec}$ に規準化し、それを 10 階建て RC 造マンショ

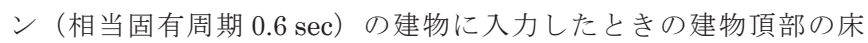
応答である。地震波の応答スペクトルを Fig.2 に示す。

実験は、Ex.1では椅子座位で、また Ex.2では仰臥位で地震動を 体験しており、実験概要を Table1に示す。今回分析の対象とした 被験者は、Ex.1 と Ex.2 の両年に渡り一定のサンプル数が確保でき

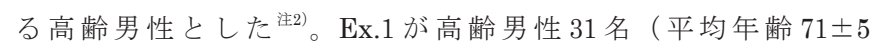
歳)、Ex.2 が 20 名（平均年齢 $67 \pm 4$ 歳）、計 51 名である。

実験手順は、以下の通りである注3)。(1)振動台へ移動する前に、 振動台横に設置した待機場所にて「STAI（State-Trait Anxiety Inventory)」と「実験前意識調查アンケート」を実施した。(2)振動台 に入って 5 分後に「1 回目の血圧・脈拍数」を測定し、その後 5 分 ごとに 2 回測定した。(3)緊急地震速報の受信直後に地震動を体験 し、(3)地震動体験直後には以下同様に 3 回の血圧・脈拍数を 5 分ご とに測定した。(4)振動台実験室から出た直後に振動台横の待機場所 にて再び「STAI」、「感覚評価アンケート」、そして「実験後意識調 查アンケート」を実施している。各種計測は、Table $2^{\text {注4) }}$ に示す通

\footnotetext{
*1 愛知工業大学工学部建築学科 教授 · 博士 (工学)

*2 北津島病院 博士 (医学)

*3 愛知淑徳大学健康医療科学部 准教授 · 博士 (医学)

*4 愛知工業大学工学部建築学科 准教授・博士 (工学) Prof., Dept. of Architecture, Aichi Institute of Technology, Dr.Eng. 
り、生理的なものと心理的な測定項目に大別される。生理的要因と は、血圧・脈拍数のことを言う。心理的要因とは、STAI・意識調 查・感覚評価のことであり、感覚評価とは「地震動の強さ・地震動 の恐怖感」などを、また意識調查とは「地震後の恐怖感・地震時自 宅に 1 人でいるときの不安・摇れの中で消火する自信」などのこと である。

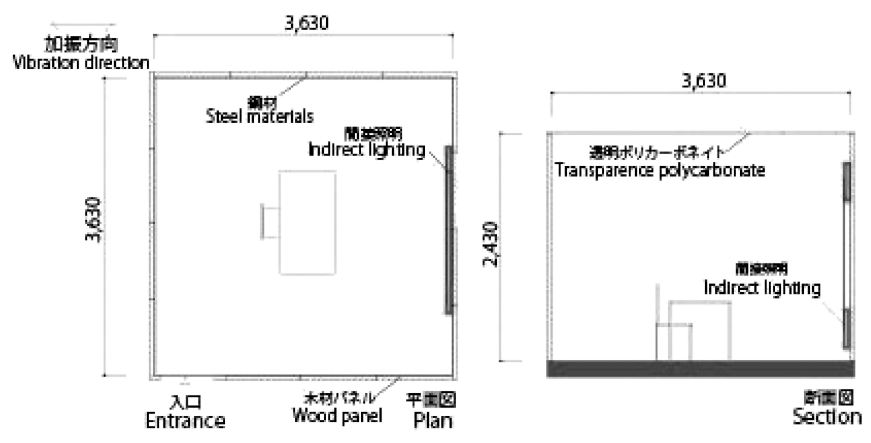

Fig. 1 Laboratory (Case of Chair seat)

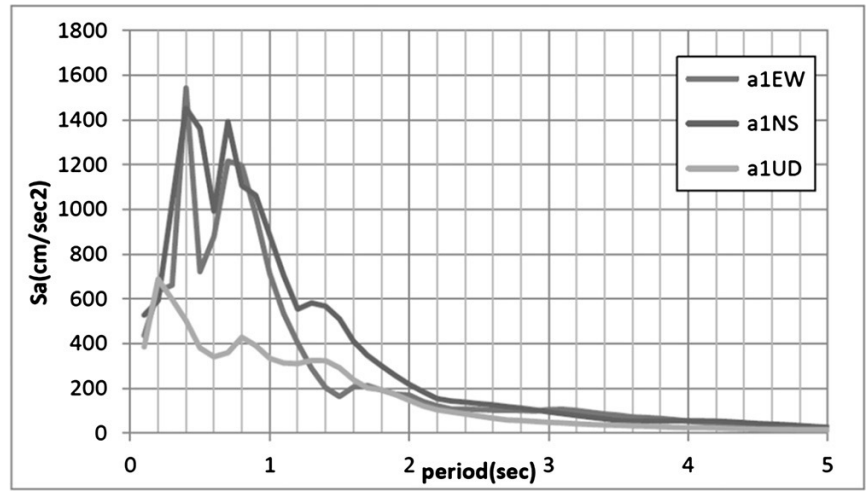

Fig. 2 Ground motion response spectra

Table 1 The experimental outline

\begin{tabular}{|c|c|c|}
\hline $\begin{array}{l}\text { Experimental kind } \\
\text { 実験の種類 }\end{array}$ & Ex.1 & Ex.2 \\
\hline $\begin{array}{c}\text { The date and time } \\
\text { 日時 }\end{array}$ & 2014.10 & 2015.10 \\
\hline $\begin{array}{l}\text { Place } \\
\text { 場所 }\end{array}$ & \multicolumn{2}{|c|}{ A.I.T. seismic test center 愛知工業大学耐震実験センター } \\
\hline $\begin{array}{l}\text { Interior illuminance } \\
\text { 室内照度 }\end{array}$ & \multicolumn{2}{|c|}{$1 \mathrm{Ix}$} \\
\hline $\begin{array}{c}\text { Earthquake wave } \\
\text { 入力地震波 }\end{array}$ & \multicolumn{2}{|c|}{$\begin{array}{l}1995 \text { Southern Hyogo Prefecture Earthquake, Observation earth } \\
\text { wave, RC The } 10 \text { th floor, Period of proper oscillation0.6 } \\
\text { 兵庫県南部地震の観測地震波を RC 造 } 10 \text { 階、固有周期 } 0.6 \text { で変換 }\end{array}$} \\
\hline $\begin{array}{l}\text { The number of } \\
\text { subjects } \\
\text { 被験者数 }\end{array}$ & $\begin{array}{l}\text { Elderly male } 31 \text {, Elderly female } 30 \\
\text { and total } 61 \text { people } \\
\text { 高齢男性 } 31 \text { 名、高齢女性 } 30 \\
\text { 名、計 } 61 \text { 名 }\end{array}$ & $\begin{array}{l}\text { Young male } 15, \text { Young female } 15, \\
\text { Elderly male } 20, \text { Elderly female } \\
20, \text { total } 70 \text { people } \\
\text { 若年男性 } 15 \text { 名、若年女性 } 15 \\
\text { 名、高齢男性 } 20 \text { 名、高齢女性 } 20 \\
\text { 名、計 } 70 \text { 名 }\end{array}$ \\
\hline $\begin{array}{l}\text { Posture } \\
\text { 被験者姿勢 }\end{array}$ & Chair seat 椅子座位 & Face up position 仰臥位 \\
\hline $\begin{array}{l}\text { Measurement i } \\
\text { tems 計測項目 }\end{array}$ & \multicolumn{2}{|c|}{9 (Refered to Table 2 表 2 参照) } \\
\hline $\begin{array}{l}\text { Measurement } \\
\text { number of times } \\
\text { 計測回数 }\end{array}$ & \multicolumn{2}{|c|}{$\begin{array}{l}\text { (1) Before ground motion 振動負荷前 } \\
\begin{array}{lll}\text { (2) After ground motion 振動負荷後 } & \text { (3) Normal time 平常時 } \\
\text { Only the blood pressure and the pulse rate are every } 5 \text { minutes, and } \\
\text { each } 3 \text { times. } \\
\text { 血圧·脈拍数のみ地震動前後 } 5 \text { 分間隔で } 3 \text { 回ずつ計測 }\end{array}\end{array}$} \\
\hline
\end{tabular}

\section{2 分析方法}

分析は、1）椅子座位と仰臥位の姿勢の違いによる地震動体験 が、生理的および心理的要因に及ぼす影響を明らかにするため、姿 勢における各測定值の差を、Wilcoxon rank sum testにて検定した (Table 3-9)。

2）椅子座位の地震動体験前と後及び仰臥位の地震動体験前と後 の違いが、生理的および心理的要因に及ぼす影響を明らかにするた め、体験前と後における各測定值の差を、Wilcoxon sign rank test にて検定した（Table 3-9）。

3）後述する実験の種類（Ex.1、EX.2）の被験者グループ間の年 齢における有意差が認められたため、説明変数を物理的・心理 的・生理的要因とした順序回帰分析 (Ordinal regression analysis) により検討を行った。

Table 2 The purpose and the feature of all kinds' measurement

\begin{tabular}{|c|c|c|c|c|}
\hline $\begin{array}{l}\text { Factor } \\
\text { 要因 }\end{array}$ & $\begin{array}{l}\text { Measurement item } \\
\text { 測定項目 }\end{array}$ & Feature 特徵 & Ex.1 & Ex.2 \\
\hline \multirow{3}{*}{$\begin{array}{l}\text { Physiological } \\
\text { factor } \\
\text { 生理的要因 }\end{array}$} & $\begin{array}{l}\text { Blood pressure } \\
\text { 血圧 }\end{array}$ & $\begin{array}{l}\text { Excitement, anxiety and a stress reflect the } \\
\text { state of the body sensitively and fluctuate. } \\
\text { 興奮、不安、ストレスなど身体の状態を敏感に } \\
\text { 反映し変動する。 }\end{array}$ & ○ & O \\
\hline & $\begin{array}{l}\text { Pulse } \\
\text { 脈拍数 }\end{array}$ & Same as above. & O & O \\
\hline & $\begin{array}{l}\text { Saliva amylase } \\
\text { 唾液アミラーゼ }\end{array}$ & $\begin{array}{l}\text { When the sympathetic nerve will be irritated and } \\
\text { be an excited state, saliva amylase is secreted } \\
\text { by nervous effect. } \\
\text { 交感神経が刺激されれ興奮状態になると、神経作 } \\
\text { 用により唾液アミラーゼが分泌される。 }\end{array}$ & 0 & $x$ \\
\hline \multirow{6}{*}{$\begin{array}{l}\text { Psychologi- } \\
\text { cal factor } \\
\text { 心理的要因 }\end{array}$} & STAI & $\begin{array}{l}\text { A transient situation reaction by anxiety is } \\
\text { measured. } \\
\text { 不安を喚起する事象に対する一過性の状況反応 } \\
\text { を測る }\end{array}$ & O & O \\
\hline & $\begin{array}{l}\text { Sense evaluation } \\
\text { questionnaire } \\
\text { 感賞評価アンケート }\end{array}$ & 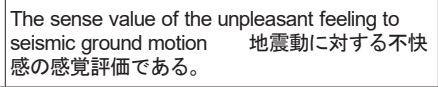 & O & O \\
\hline & $\begin{array}{l}\text { Attitude survey } \\
\text { questionnaire } \\
\text { 意識調査アンケート }\end{array}$ & $\begin{array}{l}\text { The common item which checks a conscious } \\
\text { change to an earthquake was established. } \\
\text { 地震に対する意識変化をチェックする共通項目 } \\
\text { が設定された。 }\end{array}$ & O & O \\
\hline & POMS & $\begin{array}{l}\text { The check to know the feeling state of the } \\
\text { subject. } \\
\text { 被験者の気分状態（気分や感情の変化）を知る } \\
\text { ための検査である。 }\end{array}$ & O & 0 \\
\hline & $\begin{array}{l}\text { Egogram } \\
\text { エゴグラム }\end{array}$ & $\begin{array}{l}\text { The personality test to know the individuality of } \\
\text { the subject. } \\
\text { 被験者の個性を知るための性格検查である。 }\end{array}$ & O & O \\
\hline & $\begin{array}{l}\text { Topophilia } \\
\text { トポフィリア }\end{array}$ & $\begin{array}{l}\text { It makes the sense as “love to a place" } \\
\text { 「場所への愛」という意味を持つ。 }\end{array}$ & $x$ & O \\
\hline
\end{tabular}

\section{3. 結果}

\section{1 被験者グループ間の検討}

1）年齢、血圧、脈拍について

Table 3 は姿勢別の被験者グループ（Ex.1 椅子座位と Ex.2 仰臥 位）の人数と平均年齢を示したものである。両グループ間の年齢に は有意な差が認められた（Table 3、 $\mathrm{p}=0.011$ *)。

次に、平常時（実験とは別日に測定）における姿勢別の収縮期血 圧及び脈拍数を Table 4 及び Fig. 3 に示す。収縮期血圧及び脈拍数 については実験別の被験者グループ間で有意な差が認められなかっ た（Table 4、収縮期血圧 : $p=0.596$ 、脈拍数 : $p=0.406$ 。

したがって、Ex.1 と Ex.2 の被験者グループ間では生理的（収縮 期血圧と脈拍数）な違いは見られなかったが、年齢要因による検討 が必要であると判断した。 
Table 3 The subjective number of people according to the posture and the age 姿勢別の人数と平均年齢

\begin{tabular}{|c|c|c|c|c|c|}
\hline \multirow{2}{*}{$\begin{array}{c}\text { Experiment } \\
\text { 実験 }\end{array}$} & \multirow{2}{*}{$\begin{array}{c}\text { Posture } \\
\text { 姿勢 }\end{array}$} & $\begin{array}{c}\text { Number of } \\
\text { people } \\
\text { 人数 }\end{array}$ & $\begin{array}{c}\text { Average age } \\
\text { 平均年齢 }\end{array}$ & $\begin{array}{c}\text { Standard } \\
\text { deviation } \\
\text { 標準偏差 }\end{array}$ & $\begin{array}{c}* \text { Significant } \\
\text { difference } \\
\text { admitted }\end{array}$ \\
\hline EX.1 & $\begin{array}{c}\text { Chair seat position } \\
\text { 椅子座位 }\end{array}$ & 31 人 & 70.8 & 4.8 & \multirow{2}{*}{$\mathrm{p}=0.011 *$} \\
\hline Ex.2 & $\begin{array}{c}\text { Face up position } \\
\text { 仰卧位 }\end{array}$ & 20 人 & 67.3 & 4.2 & \\
\hline
\end{tabular}

Table 4 Mean according to the posture (Normal time, Systolic blood pressure and Pulse rate) 姿勢別の平均収縮期血圧、平常時

\begin{tabular}{|c|c|c|c|}
\hline $\begin{array}{c}\text { Experiment } \\
\text { 実験 }\end{array}$ & $\begin{array}{c}\text { Posture } \\
\text { 姿勢 }\end{array}$ & $\begin{array}{c}\text { Systolic blood } \\
\text { pressure }(\mathrm{mmHg}) \\
\text { 収縮期血圧 }\end{array}$ & $\begin{array}{c}\text { Pulse rate }(\mathrm{bpm}) \\
\text { 脈拍数 }\end{array}$ \\
\hline EX.1 & $\begin{array}{c}\text { Chair seat position } \\
\text { 椅子座位 }\end{array}$ & 126.7 & 73.5 \\
\hline Ex.2 & $\begin{array}{c}\text { Face up position } \\
\text { 仰卧位 }\end{array}$ & 128.8 & 71.4 \\
\hline * Significant difference admitted & $\mathrm{p}=0.596$ & $\mathrm{p}=0.406$ \\
\hline
\end{tabular}

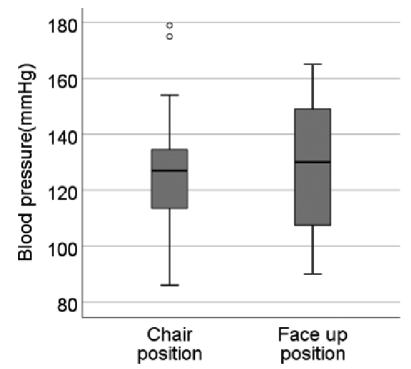

Fig. 3 Box plots of the systolic blood pressure according to the posture (Normal time)

姿勢別の収縮期血圧箱ひげ図、平常時

Table 5 Mean of the systolic blood pressure and significant test (unit: $\mathrm{mmHg}$ )

平均収縮期血圧と有意差検定

\begin{tabular}{|c|c|c|c|c|}
\hline $\begin{array}{l}\text { Experiment } \\
\text { 実験 }\end{array}$ & $\begin{array}{l}\text { Posture } \\
\text { 姿勢 }\end{array}$ & $\begin{array}{l}\text { Before ground } \\
\text { motion 振動前 }\end{array}$ & $\begin{array}{l}\text { After ground } \\
\text { motion 振動後 }\end{array}$ & $\begin{array}{c}\text { * Significant } \\
\text { difference admitted }\end{array}$ \\
\hline EX.1 & $\begin{array}{l}\text { Chair seat position } \\
\text { 椅子座位 }\end{array}$ & 128.3 & 133.3 & $p=0.080$ \\
\hline Ex.2 & $\begin{array}{l}\text { Face up position } \\
\text { 仰臥位 }\end{array}$ & 134.6 & 146.7 & $p=0.004 *$ \\
\hline \multicolumn{2}{|c|}{ * Significant difference admitted } & $p=0.247$ & $p=0.031 *$ & - \\
\hline
\end{tabular}
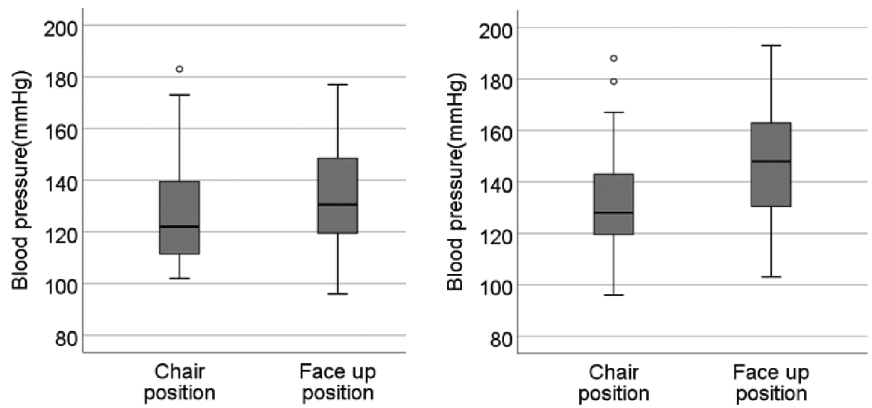

Fig. 4 Box plots of the systolic blood pressure before and after a seismic ground motion experience

(Left: Before ground motion, Right: After ground motion) 地震動体験前と後の収縮期血圧の箱ひげ図

\section{2 生理的影響}

1）収縮期血圧について

Table 5 は姿勢別の地震動体験前と後の平均収縮期血圧 （mmHg）を、Fig. 4 は姿勢別の地震動体験前と後の収縮期血圧の 箱ひげ図を示す。収縮期血圧は、地震動体験前も後も椅子座位の時 より仰臥位の時の方が、収縮期血圧值が高くなっているように見え るが、収縮期血圧を地震動体験前と後のそれぞれで椅子座位と仰臥 位の間で検定したところ、地震動体験後で有意な差が認められた

(Table 5、体験前 : $\mathrm{p}=0.247$ と体験後 : $\mathrm{p}=0.031 *$ )。

また、収縮期血圧を椅子座位と仰臥位のそれぞれについて地震動 体験前と後で検定したところ、仰臥位については有意な差が認めら れた（Table 5、椅子座位 : $p=0.080$ 、仰臥位 : $p=0.004 *$ *)。

2) 脈拍数について

Table 6 は姿勢別の平均脈拍数（bpm）を、Fig. 5 は椅子座位と 仰臥位の地震動体験前と後の脈拍数の箱ひげ図を示す。

脈拍数は、椅子座位と仰臥位の間でほとんど差がないが、地震動 体験後の仰臥位が椅子座位よりやや高いように見えるが、脈拍数を 地震動体験前と後のそれぞれで椅子座位と仰臥位の間で検定したと ころ、地震動体験前も後もそれぞれ有意な差が認められなかった (Table 6、体験前 : $p=0.954$ 、体験後 : $p=0.423)$ 。

また、脈拍数を椅子座位と仰臥位のそれぞれで地震動体験前と後 で検定したところ、仰臥位の場合地震動体験前と後で有意な差が認 められた（Table 6、椅子座位 : $\mathrm{p}=0.292$ 、仰臥位 : $\mathrm{p}=0.040 *$ ）。

Table 6 Mean of the pulse rate and significant test (unit: bpm) 脈拍数の平均値と有意差検定

\begin{tabular}{|c|c|c|c|c|}
\hline $\begin{array}{l}\text { Experiment } \\
\text { 実験 }\end{array}$ & $\begin{array}{l}\text { Posture } \\
\text { 姿勢 }\end{array}$ & $\begin{array}{l}\text { Before ground } \\
\text { motion 振動前 }\end{array}$ & $\begin{array}{l}\text { After ground } \\
\text { motion 振動後 }\end{array}$ & $\begin{array}{c}\text { * Significant } \\
\text { difference admitted }\end{array}$ \\
\hline EX.1 & $\begin{array}{c}\text { Chair seat position } \\
\text { 椅子座位 }\end{array}$ & 72.3 & 73.2 & $p=0.292$ \\
\hline Ex.2 & $\begin{array}{l}\text { Face up position } \\
\text { 仰臥位 }\end{array}$ & 72.9 & 76.9 & $p=0.040 *$ \\
\hline \multicolumn{2}{|c|}{ * Significant difference admitted } & $p=0.954$ & $p=0.423$ & - \\
\hline
\end{tabular}
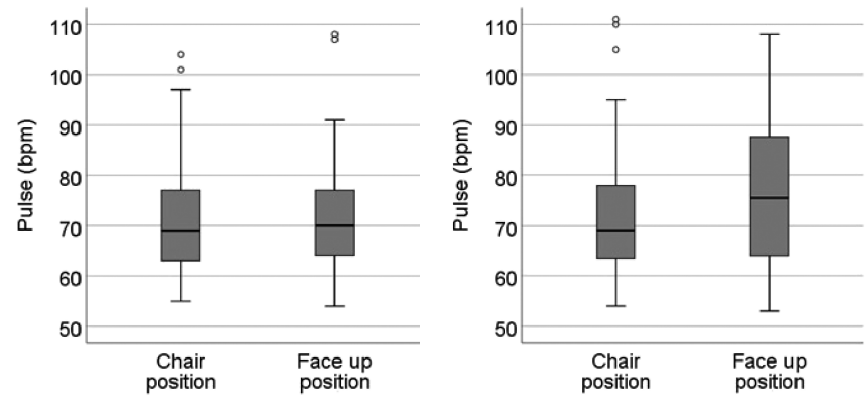

Fig. 5 Box plots of pulse rate before and after a seismic ground motion experience (unit: bpm)

(Left: Before ground motion, Right: After ground motion) 地震動体験前と後の脈拍数の箱ひげ図

\section{3 心理的影響}

1) STAI について

STAI とは一過性の不安に対する反応を計るものである（Table 2 参照)。Table 7 は椅子座位と仰臥位の STAI の平均值を、Fig. 6 は 
椅子座位と仰臥位の地震動体験前と後の STAI の箱ひげ図を示して いる。STAI は、椅子座位と仰臥位とも地震動体験前と後で 42 点 以上の高不安注5)のものは見られない。また地震動体験後は椅子座 位と仰臥位とも值がほとんじ変わらない。

STAI を地震動体験前と後のそれぞれで椅子座位と仰臥位の間で 検定したところ、地震動体験前と後でそれぞれ有意な差が認められ なかった（Table 7、体験前 : $p=0.608$ 、体験後 : $p=0.678 ） 。$

次に、椅子座位と仰臥位の間のそれぞれについて地震動体験前と 後で検定したところ、それぞれ有意な差が認められなかった（Table 7、椅子座位 : $p=0.073$ 、仰臥位 : $p=0.075)$ 。

Table 7 Mean of the STAI and significant test STAI の平均值と有意差検定

\begin{tabular}{|c|c|c|c|c|}
\hline $\begin{array}{c}\text { Experiment } \\
\text { 実験 }\end{array}$ & $\begin{array}{c}\text { Posture } \\
\text { 姿勢 }\end{array}$ & $\begin{array}{c}\text { Before ground } \\
\text { motion 振動前 }\end{array}$ & $\begin{array}{c}\text { After ground } \\
\text { motion 振動後 }\end{array}$ & $\begin{array}{c}\text { * Significant } \\
\text { difference admitted }\end{array}$ \\
\hline EX.1 & $\begin{array}{c}\text { Chair seat position } \\
\text { 椅子座位 }\end{array}$ & 37.5 & 39.3 & $\mathrm{p}=0.073$ \\
\hline Ex.2 & $\begin{array}{c}\text { Face up position } \\
\text { 仰臥位 }\end{array}$ & 38.4 & 40.5 & $\mathrm{p}=0.075$ \\
\hline * Significant difference admitted & $\mathrm{p}=0.608$ & $\mathrm{p}=0.678$ & - \\
\hline \multicolumn{4}{|r|}{} \\
\hline
\end{tabular}
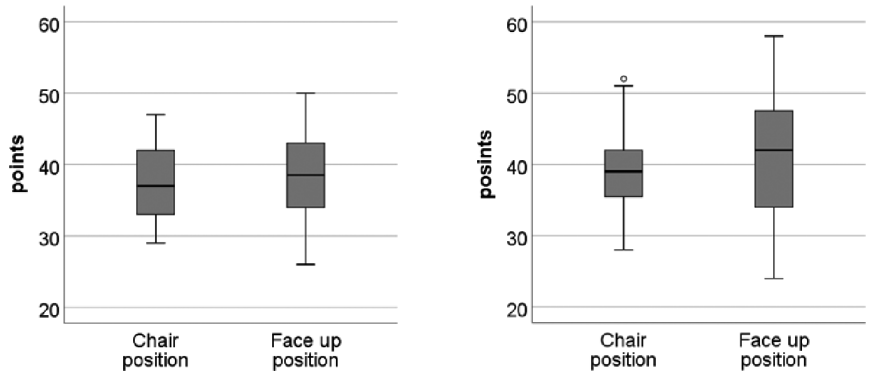

Fig. 6 Box plots of STAI before and after a seismic ground motion experience (Left: Before ground motion, Right: After ground motion) 地震動体験前と後の STAI の箱ひげ図
2）地震動に対する感覚評価について

感覚評価アンケートは、地震動体験後に計測したもので、地震動 の感じ方についての結果を間隔尺度として定量化し、評価值を 1 か ら 5 までの 5 段階（摇れの強さなら「1」はとても弱い、「2」は弱 い、「3」がどちらでもない、「4」は強い、「5」はとても強い）で表 した。

Table 8 は姿勢別の「地震動の大きさ」、「地震動の強さ」、「地震 動の恐怖感」、「地震動の体感時間」についての平均值を示したもの である。「地震動の大きさ」、地震動の強さ」、「地震動の恐怖感」 は、「地震動の体感時間」を除くと、体験後はいずれも評価值 4 以 上のものが多かった。

Fig. 7 は感覚評価の評価值の箱ひげ図を示したものである。地震 動の強さと体感時間については椅子座位と仰臥位で違いがあるよう に見えるが、感覚評価の評価值を椅子座位と仰臥位の間で検定した ところ、「地震動の強さ」は有意な差が認められた（Table8、強 さ : $\mathrm{p}=0.020 *$ )。しかし、「地震動の大きさ」、「地震動の恐怖 感」、地震動の体感時間」については椅子座位と仰臥位の間で有意 な差が認められなかった（Table8、地震動の大きさ： $\mathrm{p}=0.058$ 、地 震動の恐怖感 : $p=0.681$ 、地震動の体感時間 $: p=0.210)$ 。

3）地震に対する意識調査アンケートについて

意識調査アンケートは、「0 全く違う」、「1いくらか」、「2まあそ うだ」、「3その通りだ」とする 4 段階評価で、19 項目の設問注6) か ら構成されている。その内訳は実験前アンケートでは、被験者の基 本属性に係る 8 項目と、地震対策の必要性、防災訓練参加の有効 性、地震時の気持ちなどの 11 項目の設問があり、実験後アンケー トでも同じ質問をしている。ここでは代表的な「地震後の恐怖 感」、「自宅に 1 人でいる時の不安」、「摇れの中で消火する自信」、 「地震時絶望的な気持ち」の 4 項目について考察した。Table 9 は姿 勢別の地震動体験前と後の 4 項目の平均值を、Fig. 8 は意識評価の 箱ひげ図を示したものである。仰臥位については、地震後の恐怖感

Table 8 The sense value to Seismic Ground Motion and significant test 地震動に対する感覚評価の平均値と有意差検定

\begin{tabular}{|c|c|c|c|c|c|}
\hline $\begin{array}{c}\text { Experiment } \\
\text { 実験 }\end{array}$ & $\begin{array}{c}\text { Posture } \\
\text { 姿勢 }\end{array}$ & $\begin{array}{l}\text { 1) Size of } \\
\text { ground motion } \\
\text { 地震動の大きさ }\end{array}$ & $\begin{array}{c}\text { 2) Strength of } \\
\text { ground motion } \\
\text { 地震動の強さ }\end{array}$ & $\begin{array}{l}\text { 3) Scare of } \\
\text { ground motion } \\
\text { 地震動の恐怖感 }\end{array}$ & $\begin{array}{l}\text { 4) Sense of } \\
\text { time length } \\
\text { 地震動体感時間 }\end{array}$ \\
\hline EX.1 & $\begin{array}{c}\text { Chair seat position } \\
\text { 椅子座位 }\end{array}$ & 4.2 & 4.3 & 4.1 & 3.3 \\
\hline Ex.2 & $\begin{array}{c}\text { Face up position } \\
\text { 仰臥位 }\end{array}$ & 4.4 & 4.6 & 4.1 & 3.8 \\
\hline$*$ Significant difference admitted & $\mathrm{p}=0.058$ & $\mathrm{p}=0.020 *$ & $\mathrm{p}=0.681$ & $\mathrm{p}=0.210$ \\
\hline
\end{tabular}
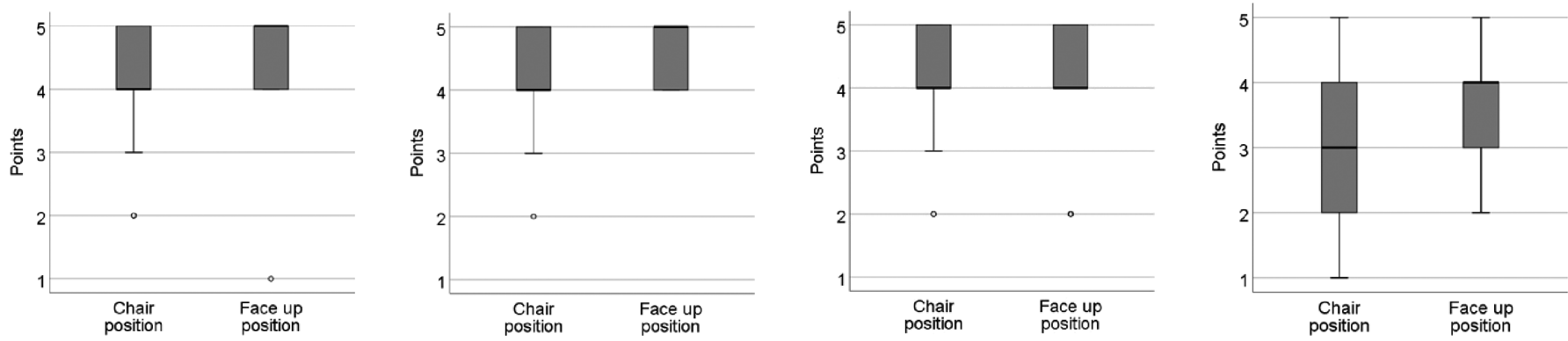

Fig. 7 Sense value to Seismic Ground Motion (Left, a. Size of ground motion,

b. Strength of ground motion, c. Scare of ground motion, d. Sense of time length) 地震動に対する感覚評価 
と摇れの中で消火する自信の感覚平均值で地震動体験前と後ではか なりの差がみられる。これに対して、自宅に 1 人でいるときの不安 や地震時絶望的な気持ちになる感覚については地震動体験前と後で ほとんど差がみられない。一方、椅子座位については 4 項目とも地 震動体験前と後で大きな違いは見られないが、検定を行いそれぞれ 以下に検証を行った。

ア）地震後の恐怖感注7)

椅子座位と比べて仰臥位は地震後の恐怖感が地震動体験前と後と もやや強い。また仰臥位は体験後に恐怖感を強く感じているように 見えるが、椅子座位と仰臥位のそれぞれについて地震動体験前と後 で検定したところ、いずれも有意な差が認められなかった（Table 9、椅子座位 $: p=0.581$ 、仰臥位 $: p=0.064)$ 。

また、地震動体験前と後のそれぞれで椅子座位と仰臥位の間で検 定したところ、地震動体験前と後ともそれぞれ有意な差が認められ なかった（Table 9、体験前 $: p=0.509$ 、体験後 $: p=0.231 ） 。$

イ）自宅に 1 人でいるときの不安

仰臥位は椅子座位と比べて地震動体験前と後とも 1 人でいるとき の不安を感じていない傾向がある (Table 9)。しかし、地震動体験 後にはいずれの姿勢でもやや不安を感じるようになるように見える
が、椅子座位と仰臥位のそれぞれについて地震動体験前と後で検定 したところ、いずれも有意な差が認められなかった（Table 9、椅 子座位 $: p=0.143$ 、仰臥位 $: p=0.710)$ 。

また、地震動体験前と後のそれぞれで椅子座位と仰臥位の間で検 定したところ、地震動体験前と後ともそれぞれ有意な差が認められ なかった（Table 9、体験前 : $p=0.453$ 、体験後 $: p=0.282$ )。

ウ）摇れの中で消火する自信

地震動体験前にはいずれの姿勢でも摇れの中で消火活動ができる かどうかは、どちらともいえない状況である（Fig. 8）。しかし、仰 臥位は地震動体験後に、明確に消火活動ができる自信がないと感じ るように見えるが、椅子座位と仰臥位のそれぞれについて地震動体 験前と後で検定したところ、仰臥位については有意な差が認められ た（Table 9、椅子座位 : $\mathrm{p}=0.629$ 、仰臥位 : $\mathrm{p}=0.036 *$ )。

また、地震動体験前と後のそれぞれで椅子座位と仰臥位の間で検 定したところ、地震動体験の前と後ともそれぞれ有意な差が認めら れなかった（Table 9、体験前 : $p=0.904$ 、体験後 : $p=0.134$ )。

エ）地震時絶望的な気持ち

いずれの姿勢でも、地震動体験前でも後でも地震時絶望的な気持 ちになる傾向がある（Table 9)。しかし、仰臥位においては、地震

Table 9 The significant difference in the attitude survey questionnaire 意識調査アンケートにおける有意差

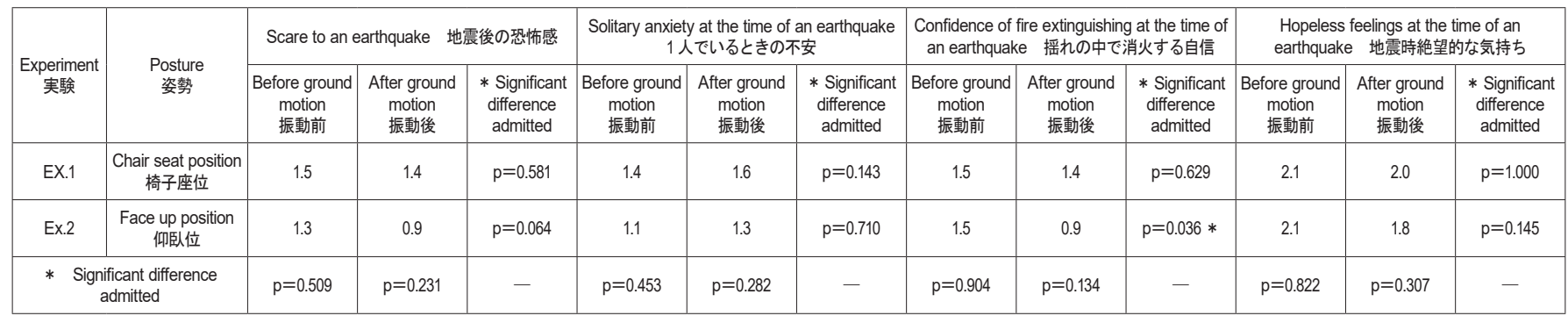
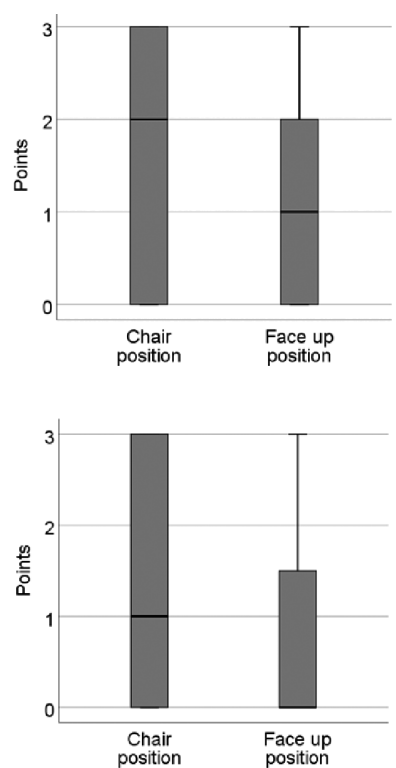
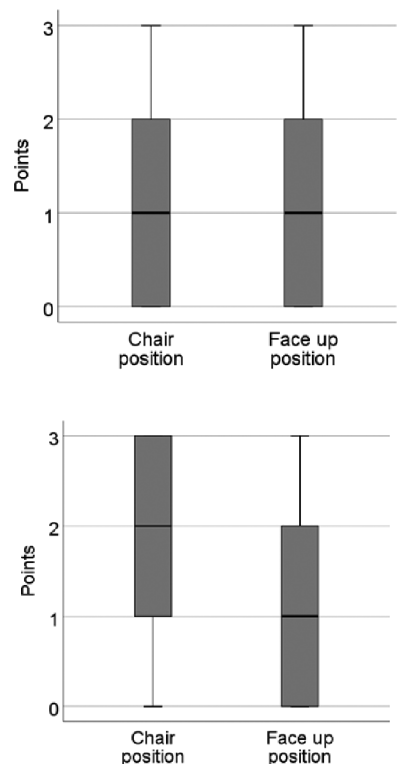
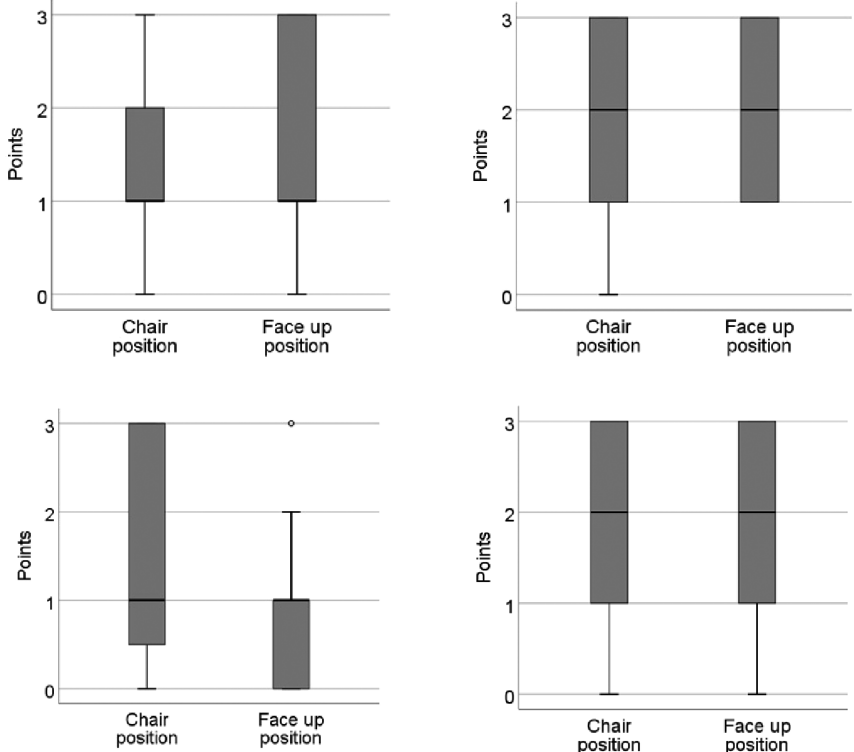

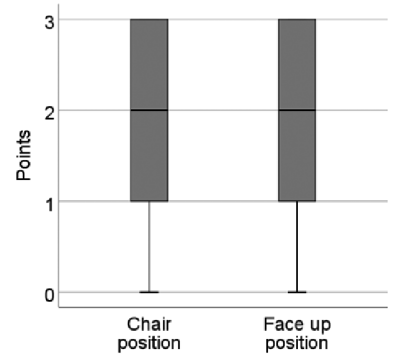

Fig. 8 Attitude survey questionnaire The upper row, before a seismic ground motion experience and a lower berth are after a ground motion experience. a. Scare to an earthquake, b. Solitary anxiety at the time of an earthquake,

c. Confidence of fire extinguishing at the time of an earthquake, $d$. Hopeless feelings at the time of an earthquake 意識調査の箱ひげ図 (上段は地震動体験前、下段は地震動体験後)

（左から、a. 地震後の恐怖感、b. 1 人でいるときの不安、c. 摇れの中で消火する自信、d. 地震時絶望的な気持ち) 
動体験の後では強い地震が起きたときは絶望的な気持ちが多少解消 されるように見えるが、椅子座位と仰臥位のそれぞれについて地震 動体験前と後で検定したところ、いずれも有意な差が認められな かった（Table 9、椅子座位 : $p=1.000$ 、仰臥位 : $p=0.145$ ）。

また、地震動体験前と後のそれぞれで椅子座位と仰臥位の間で検 定したところ、地震動体験前と後ともそれぞれ有意な差が認められ なかった（Table 9、体験前 : $p=0.822 、$ 体験後 $: p=0.307$ ）。

\section{4. 順序回帰分析による考察}

3.1 で示した通り、物理的要因である年齢が Ex.1 と Ex.2のグ ループ間で有意な差が認められた。そこで、調整するために年齢を 含めた物理的・生理的 • 心理的要因について $\mathrm{SPSS}^{\text {注8) }}$ を使用して
重回帰分析を行うこととした。目的変数を感覚評価の評価值におい て姿勢間で有意な差がみられた「地震動の強さ」とした。また説明 変数に順序データが含まれているため順序回帰分析を行うこととし た。手順は以下のとおりである（Table 10）。

1）モデル適合情報において有意確率が $\mathrm{p}=0.000<0.05$ なのでパ ラメーターの係数はすべて 0 でなく問題はない。

2）モデルの適合度については有意確率が $\mathrm{p}=1.000>0.05$ なので データはモデルに適合している。

3）疑似 $\mathrm{r}^{2}$ は $0.613 \sim 0.704$ で 1 にやや近いことから、モデル式の 当てはまりは良いと言える。

4）物理的（年齢、姿勢） - 生理的（収縮期血圧、脈拍数） - 心理 的（STAI、「地震動の大きさ」、「地震動の強さ」、「地震動の

Table 10 Ordinal regression analysis 順序回帰分析

\begin{tabular}{|c|c|c|c|c|}
\hline \multicolumn{5}{|c|}{ Model relevant information モデル適合情報 } \\
\hline $\begin{array}{c}\text { A model } \\
\text { モデル }\end{array}$ & $\begin{array}{c}\text { Logarithm likelihood } \\
-2 \text { 対数尤度 }\end{array}$ & $\begin{array}{c}\text { R square } \\
\text { カイ 2 乗 }\end{array}$ & $\begin{array}{c}\text { Degree of freedom } \\
\text { 自由度 }\end{array}$ & $\begin{array}{c}\text { Significant probability } \\
\text { 有意確率 }\end{array}$ \\
\hline $\begin{array}{c}\text { Only a section } \\
\text { 切片のみ }\end{array}$ & 104.713 & & & \\
\hline $\begin{array}{c}\text { Last } \\
\text { 最終 }\end{array}$ & 56.245 & 48.468 & 12 & 0.000 \\
\hline
\end{tabular}

\begin{tabular}{|c|c|c|c|}
\hline \multicolumn{4}{|c|}{ The degree of fitness 適合度 } \\
\hline & $\begin{array}{c}\text { R square } \\
\text { カイ 2 乗 }\end{array}$ & $\begin{array}{c}\text { Degree of freedom } \\
\text { 自由度 }\end{array}$ & $\begin{array}{c}\text { Significant probability } \\
\text { 有意確率 }\end{array}$ \\
\hline Pearson & 70.696 & 138 & 1.000 \\
\hline 逸脱 & 56.245 & 138 & 1.000 \\
\hline
\end{tabular}

\begin{tabular}{|c|c|}
\hline \multicolumn{2}{|c|}{ Pseudo-R square 疑似 $\mathrm{r}$ 乗 } \\
\hline Cox と Snell & 0.613 \\
\hline Nagelkerke & 0.704 \\
\hline McFadden & 0.463 \\
\hline
\end{tabular}

Table 11 Parameter assessed value パラメーター推定值

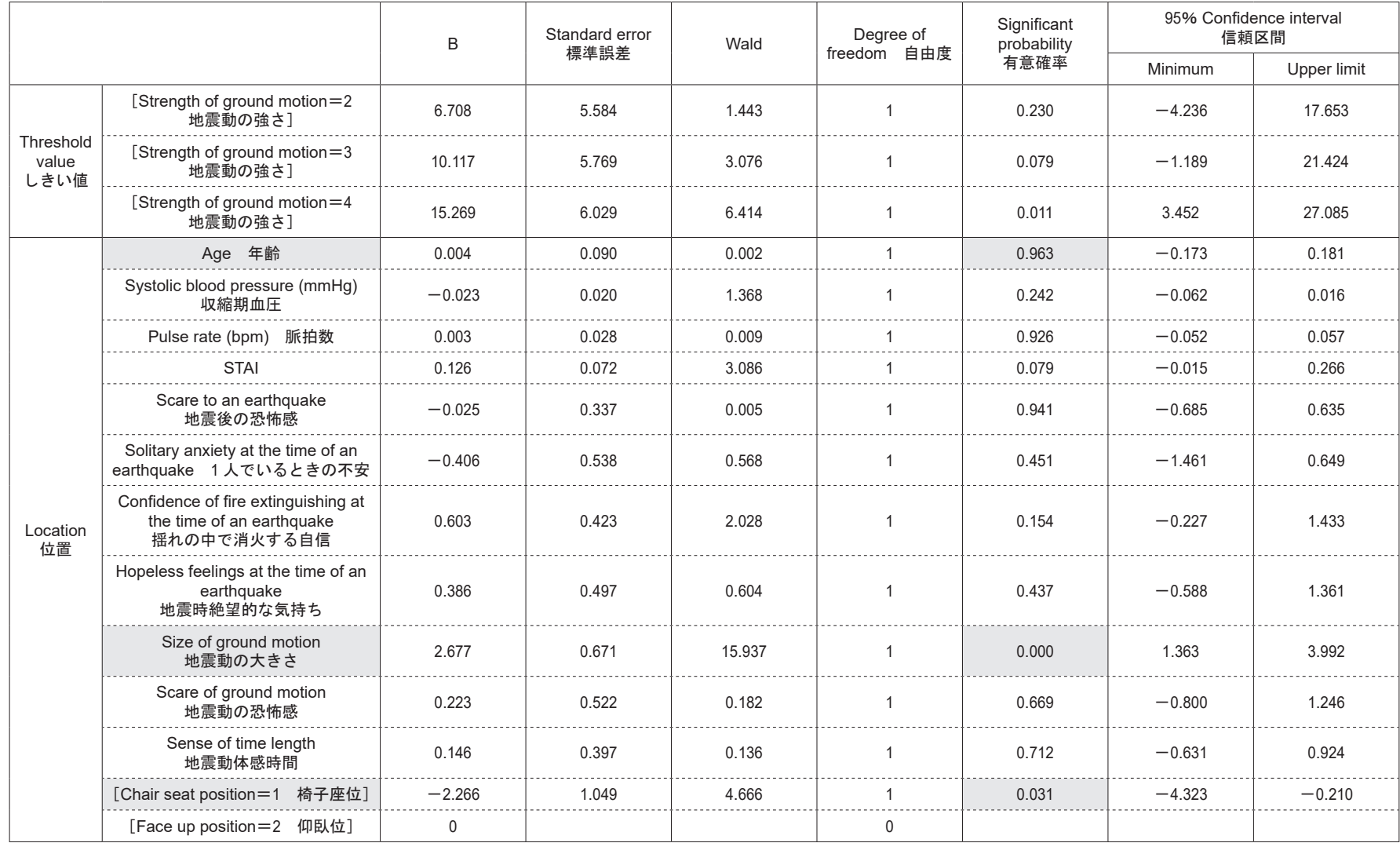


恐怖感」、「地震動の体感時間」、「地震後の恐怖感」、「自宅に 1 人でいるときの不安」、「摇れの中で消火する自信」、「地震 時絶望的な気持ち」）の説明変数のパラメーター推定值を示す

(Table 11)。その結果、「年齢」については有意確率（95\%信 頼区間）が 0.963 であることから除外し、その他の各変数も 同様に除外した。

5）感覚評価の地震動の強さは、「姿勢」と「地震動の大きさ」で 有意確率が 0.05 より小さいので、これらによって違いがある と判断される。特に、姿勢 $=2$ (仰臥位) のパラメーターを 0 に設定しているので仰臥位に比べて椅子座位の方が摇れの強 さに違いがあると言える。

以上の結果から、「地震動の強さ」は「姿勢」と「地震動の大き さ」によって説明できることが明らかとなった。

\section{5. 結論}

本研究は、地震動から受ける高齗男性の生理的・心理的反応が姿 勢の違いによってどのような影響を受けるかについて検討した。

明らかとなった主な結果は以下の通りである。

椅子座位と仰臥位とでは地震動による生理的・心理的な影響の違 いが認められた。

・地震動体験後においては椅子座位と比べて仰臥位のほうが収縮 期血圧は高くなる。

・地震動体験後においては椅子座位と比べて仰臥位のほうが地震 動の強さを感じやすくなる。

地震動体験後は体験前と比べて、

・仰臥位における収縮期血圧は高くなる。

・仰臥位における脈拍数は高くなる。

・仰臥位における消火する自信が低下寸る。

仰臥位においては地震動体験によって先に挙げた明確な生理 的・心理的反応の違いが認められた。これに対して、椅子座位では 地震動体験前と後では生理的にも心理的にも明確な違いが認められ なかった。

また、順序回帰分析から、地震動の強さは「年齢」による影響は 認められず、「姿勢」と「地震動の大きさ」で説明できることが明 らかとなった。

以上のことから、椅子座位では地震動体験前と後の影響の違いが 今回の実験ではほとんど認められないのに対し、仰臥位では地震動 による影響が生理的にも心理的にも増幅されやすいことが想定され る。その反面、寝た状態の仰臥位のほうが 1 人でいるときの不安や 地震時絶望的な気持ちがやや和らげられる側面を持つことが示唆さ れた。

また、寝た状態の仰臥位では被験者グループ全体が地震動の強さ をほぼ強く感じるのに対し、椅子座位グループについては地震動の 強さ感覚值が分散し、地震動を強く感じない被験者もみられた。 よって、椅子座位という姿勢は立位に近く活動がしやすいため被験 者によっては地震動の強さの低減につながる可能性があることが示 唆された。

こうした知見を踏まえて、今後は年齢や性差についても分析 し、防災対策に生かす必要がある。

\section{謝辞}

本研究は平成 $21 \sim 27$ 年度文部科学省科学研究費補助金（基盤 （c）、代表：建部謙治）を受けて実施したものである。実験実施に 当たっては矢頭浩平 (ミニテック)、渡邊優（清水建設）、杉浦哲 (大豊精機)、高山恵太 (岩倉市役所)、渡邊康平（日本国土開発） の各氏とともに多くの被験者の方々にご協力を賜りました。また稿 を終わるに鑑み、本研究の共同研究者である天野寛元愛知県医師会 主任研究員の心理分析に改めて敬意を表するとともに、宮治眞名古 屋市立大学客員教授のご助言に深謝します。

\section{注}

注 1）照度は夜間時起きているときに地震のため停電になった状況を想定し た。現実的には安全・倫理上暗闇での実験を行うことはできないため照度 $1 \mathrm{~lx}$ とした。被験者には、「この実験（1 lx）は停電時の暗闇を想定したも のです」と教示した。

注 2）高齢女性を扱っていない理由は、今回は被験者グループ間の年齢によ る有意差問題の検証を明確にするため、高齢男性に限定して考察した。

注 3）愛知工業大学の倫理委員会の承認に基づき、事前に被験者に振動台実 験参加の同意を得ている。被験者の同意及び実験に関する示唆に関して は、「研究計画の背景と目的」「調查方法」「学術上の貢献」「個人、施設へ の不利益・危険性」「倫理的配慮」などを十分に説明したうえで、「実験参 加取りやめの自由」「発生の可能性のある事態」「保険への加入」など 7 項 目からなる内容に対し確認・押印した同意書を互いに取り交わしている。 実験当日は手順に従い、振動台入室前に、「この実験は停電時の暗闇を想 定したものです。これから振動台に入り実験を行います」などと教示し、 実験を行っている。

注 4) Ex.1 は唾液アミラーゼを測定、Ex.2 はトポフィリアの測定を追加で 行っている。

注 5) STAI は状態不安を得点で表し、一般的に 24 点から 50 点の間に分布 し、既報 4 と同様に標準得点の 42 点以上を高不安と判断した。

注 6）意識調査アンケートの設問 19 項目は以下の通りである。

1. 年齢、2．性別、3．あたなは過去に大きな病気をしましたか、4.あな たの現在のお住まいは、5. あなたは過去に震度 5 以上の震災体験があり ますか、6.これまでに自分の住んでいる家屋の耐震診断をしたことがあ りますか、7. 家族や知人と話し合って、共通の避難場所を決めています か、8．緊急地震速報を知っていますか、9. 地震対策の必要性はそれれど 感じていない、10．地震に対する恐怖感はあまり感じていない、11．居宅 に一人で居るときに地震に遭遇した場合、身近に誰かがいないと不安だと 思う12. 建物が崩壊しても、よほどのことがない限り脱出できると思 う、13. 地震の摇れを感じているときでもガスコンロやストーブに火がつ いていれば、素早く消火する自信がある、14. 南海・東南海地震に対する 情報には注意を払う必要があると思う、15. 防災訓練への参加は必要、有 効だと思う、16. 地震は火事と比べて恐怖感が強いと思う、17. 強い地震 が起きたときは絶望的な気持ちになると思う、18. 緊急地震速報は必要で あると思う。19. 強い地震を自宅で遭遇した場合、以下の項目について、 重要と思われる順に全て番号をつけて下さい(以下略)。

注 7）「地震時の恐怖感」については「・・あまり感じていない」というょ うに否定的な設問内容である。その他の 3 項目は「・・1人の時不安に 感じる」のように肯定的な質問内容となっている。

注 8) IBM 社の SPSS の Ver.26 を使用している。

\section{参考文献}

1) Shigeo Kotake, Akito Korei, Why People Cannot Keep Standing under Strong Earthquake: (Aging Effect to Human Postural Control in Quiet Standing), Symposium on sports engineering: Symposium on human dynamics. 2018 (0), D-19, 2018

小竹茂夫, 是井昭人: 強地震動下で人が立っていられなくなる理由：(ヒト 静止立位姿勢制御の老化による影響。シンポジウム : スポーツ・アンド・ ヒューマン・ダイナミクス講演論文集, 2018(0), D-19, 2018

2) Kenji Tatebe, Moriaki Suzuki, Makoto Miyaji, Hiroshi Amano, Masayoshi Ide, Ken kato: Study on psychological and physiological effects of earthquake motion on the human body of the elderly Influence to a mind and body by the posture, Bulletin of Aichi Institute of Technology, 
Vol. 51, pp. 110-115, 2016

建部謙治, 鈴木森晶, 宮治眞, 天野寛, 井出政芳, 加藤憲他：地震動が高齢者 一及ぼす生理的 - 心理的影響，姿勢による影響を中心として，愛知工業大 学研究報告, 51 号, pp. 110-115, 2016

3) Kenji Tatebe, Masayoshi Ide, Ken Kato, Kuniyoshi Miyashita: Experimental study on psychological and physiological effects of earthquake motion on the elderly human body Part 3, Physiological Influence by an Earthquake Motion which aimed at an Individual, Journal of Architecture and Planning (Transactions of AIJ), Vol. 82, No. 742, pp. 3105-3111, 2017. 12

建部謙治, 井出政芳, 加藤憲, 宮下邦義：地震動による高齢者への心理・生理 学的影響に関する実験的研究 その 3 , 個人の特性に着目した地震動の影 響の分析, 日本建築学会計画系論文集, Vol. 82, No. 742, pp. 3105-3111, 2017. 12

4) Kenji Tatebe, Makoto Miyaji, Hiroshi Amano, Masayoshi Ide: Experimental study on psychological and physiological effects of earthquake motion on the elderly human body Part 2 , The relation of psychological influence and physiologic consequence by earthquake motion, Journal of Architecture and Planning (Transactions of AIJ), Vol. 80, No. 708, pp. 283-288, 2015. 2

建部謙治, 宮治眞, 天野寛, 井出政芳: 地震動による高齢者人の心理・生理学 的影響に関する実験的研究 その 2 ，地震動による心理学的影響と生理と の関係, 日本建築学会計画系論文集, Vol. 80, No. 708, pp. 283-288, 2015. 2

5) Kenji Tatebe, Makoto Miyaji, Hiroshi Amano, Masayoshi Ide: Experimental study on psychological and physiological effects of earthquake motion on the elderly human body Part 1, The Physiological Efects of the Earthquake Motion on the Human Body, Journal of Architecture and Planning (Transactions of AIJ), Vol. 79, No. 697, pp. 651657, 2014.3

建部謙治, 宮治眞, 天野寬, 井出政芳: 地震動による高齢者への心理・生理学 的影響に関する実験的研究 その 1 , 地震動の人体に及ぼす生理的影響, 日本建築学会計画系論文集, Vol. 79, No. 697, pp. 651-657, 2014. 3

6) Kenji Tatebe, Masayoshi Ide, Ken Kato, Kuniyoshi Miyashita, Hideki Nozawa: Experimental study on psychological and physiological effects of earthquake motion on the elderly human body Part 4, Analysis of the influence of time-lagged preliminary notice of seismic ground waves by Earthquake Early Warning, Journal of Architecture and Planning (Transactions of AIJ), Vol. 84, No. 758, pp. 801-808, 2019. 4 建部謙治, 井出政芳, 加藤憲, 宮下邦義, 野澤英希：地震動による高齢者への 心理・生理学的影響に関する実験的研究 その 4, 緊急地震速報を利用し た地震動予告の時間差による影響分析, 日本建築学会計画系論文集, Vol. 84, No. 758, pp. 801-808, 2019. 4

7) Taiki Hara, Ken Imada: At the time of leg walking under the condition which changed the brightness in the apoplexy one paralytic case with fall reki which is at the time of night walking, muscular activity, Japanese Society of Physical Terapy, the 49th time Japanese physical therapy art and science meeting proceedings and Vol. 41, Suppl. No. 2, 2013. 5 原大樹, 今田健: 夜間歩行時の転倒歷を有する脳卒中片麻痺症例における明 るさを変化させた条件下の下肢歩行時筋活動, 日本理学療法学会, 第 49 回 日本理学療法学術大会抄録集, Vol. 41, Suppl. No. 2, 2013.5 


\title{
INFLUENCE ANALYSIS OF SEISMIC GROUND MOTION \\ ON ELDERLY MALES BY DIFFERENCE IN POSTURES
}

\author{
Kenji TATEBE*1, Masayoshi IDE ${ }^{* 2}$, Ken KATO*3 \\ and Hideki NOZAWA*4 \\ ${ }^{* 1}$ Prof., Dept. of Architecture, Aichi Institute of Technology, Dr.Eng. \\ ${ }^{* 2}$ Kitatsushima Hospital, $\mathrm{Ph} . \mathrm{D}$. \\ ${ }^{* 3}$ Assoc. Prof., Faculty of Health and Medical Sciences, Aichi Shukutoku University, Ph.D. \\ ${ }^{* 4}$ Assoc. Prof., Dept. of Architecture, Aichi Institute of Technology, Dr.Eng.
}

The purpose of this research was to make clear the physiological and psychological influence of earthquake motion on posture. 51 elderly male subjects were used by an experiment using vibration table.

The main results are summarized as follows.

1) A difference in the physiological and psychological influence of the seismic ground motion was seen between the chair seat and the face up position.

2) The difference in the physiological and psychological response to a seismic ground motion experience was seen clearly in face up position.

3) The face up position showed high systolic blood pressure compared with a chair seat.

4) The face up position feels seismic ground motion more intensely than a chair seat.

5) The systolic blood pressure in the face up position becomes high after an experience compared with before the seismic ground motion experience.

6) The pulse rate in the face up position becomes high after a ground shock experience compared with before the experience.

7) In the face up position, confidence of fire extinguishing falls after a ground shock experience compared with before the experience.

8) On the other hand, a difference in the physiological and psychological response wasn't seen clearly in the chair seat posture.

9) The following became clear through multi regression analysis: Sense of seismic ground motion strength was not influenced by age. Sense of seismic ground motion strength can be explained by posture and sense of seismic magnitude.

(2020 年 4 月 8 日原稿受理, 2020 年 6 月 2 日採用決定) 